\title{
Unraveling complex relations between forest-cover change and conflicts through spatial and relational analyses
}

\author{
Irene Pérez-Llorente ${ }^{1}, \underline{\text { M. Isabel Ramírez }}{ }^{1}, \underline{J a i m e ~ P a n e q u e-G a ́ l v e z ~}^{1}$, Claudio Garibay Orozco $^{1}{ }^{\text {and Rafael González-López }}{ }^{2}$
}

\begin{abstract}
Despite the increasing prevalence of forest-cover change and conflicts, most studies have been unable to unravel the complex relations between the two processes. We attribute this failure to methodological limitations. We put forward an alternative approach that combines different datasets (remote sensing, GIS, local narratives, official censuses, newspaper articles), methods (spatial and relational analyses), and scales (subregions, economic sectors, land-based activities) to create a robust explanation of the relations between different intensities of forest-cover change and conflict in the Meseta Purépecha region, central Mexico. This is an important forest region, inhabited by indigenous and mestizo peasants; it has a worldwide reputation for community forestry and is also the epicenter of international avocado production. Forest-cover change is intense and there are recurrent episodes of conflict. We clustered communities in three subregions according to their patterns of forest-cover change. We analyzed the spatial patterns of forest-cover change and conflicts and we characterized the structure and function of the different economic sectors to unravel the nonlinear, interdependent (and sometimes contradictory) relations among these processes. We found that avocado production has differentially shaped the composition and working of society within each subregion, leading to three diverging patterns. Avocado production has provoked conflicts over landownership and over illegal logging in nearby areas. In some areas, a low incidence of conflicts over forest clearance might be explained by high profits, coercion, and violence. We suggest that, by combining spatial and relational analyses, we can integrate and check the congruence of nonequivalent representations from quantitative sources and observant participation at different scales and explain the heterogeneity that processes display across space. Our methodological approach can thus improve our understanding of similar and other complex and uncertain environmental problems elsewhere, especially when accurate or appropriate data are missing.
\end{abstract}

Key Words: central Mexico; complexity theory; environmental conflicts; land-cover/land-use change; uncertainty

\section{INTRODUCTION}

Forest-cover change (FCC) and conflicts related to the access and use of forest resources have become increasingly apparent in this century (Koning et al. 2008). The growing literature on the subject has put forward widely diverse theories to explain the relations between FCC and conflicts, and no agreement has been reached (Rustad et al. 2008). For instance, land tenure insecurity created by agrarian conflicts can encourage deforestation (Araujo et al. 2009, Aldrich et al. 2012). Agrarian conflicts have also been associated with deforestation because timber extraction and (illegal) cash crops provide the means to finance conflict (Glew and Hudson 2007, Rincón-Ruiz and Kallis 2013, McSweeney et al. 2014). Others have asserted that deforestation provokes environmental conflicts and resistance movements (Affolderbach 2011, Gerber and Veuthey 2011, Seghezzo et al. 2011), that "conservation enclosures" designed to prevent deforestation may also trigger conflicts (Corson 2011, Peluso and Lund 2011, Rocheleau 2015), or that violence and conflicts can lead to the abandonment of agricultural areas or to "gunpoint or narcoconservation" (McNeely 2003, Suthakar and Bui 2008, SánchezCuervo and Aide 2013). Some authors have argued that both FCC and conflicts are caused by mutually affecting factors operating at multiple scales, such as the expansion of cattle ranching fostered by increases in global meat demand, the historical agrarian struggles and violence in the Brazilian Amazon, and the combination of poverty and drug trafficking in Colombia and Mexico (O'Brien 1998, Rodrigues et al. 2009, Hecht and Cockburn 2010).
This diversity of narratives may be due to the wide range of processes of different intensity and scale encompassed by conflicts, but also to the use of disciplinary or multidisciplinary methods that may fail to apprehend the extent of the social and natural complexity inherent in both FCC and forest conflicts. Complex processes are subject to uncertainty, emergence, adaptiveness, nonlinear relations, and "chicken or egg" paradoxes (Funtowicz and Ravetz 1994, Rosen 1999, Giampietro et al. 2014). Such complex systems cannot be formalized into a model without losing most of their truth, because the definition, observation, and management of the research problem implies value judgement (Rosen 2012). They thus require the use of multiple epistemologies and simultaneous nonequivalent descriptions (González-López and Giampietro 2017, Saltelli and Giampietro 2017). Moreover, the processes underlying FCC and conflicts vary depending on the location, resolution, and extent of the analysis (Veldkamp and Lambin 2001). The use of a regional case study with varying degrees of FCC and conflicts and different scales could enhance our understanding of such processes by capturing part of their heterogeneity.

Several recent studies have explored the complexity and heterogeneity of social-ecological changes associated with conflicts. For instance, some authors have combined spatial and statistical analysis with case studies to explain local land conflicts as a result of the interaction of scalar forces that structure resource access (Simmons 2004), or deforestation and forest-related violence as conjoint outcomes of multiscale forest governance (Durán et al. 2011). Hanaček and Rodríguez-Labajos (2018) used

${ }^{1}$ Centro de Investigaciones en Geografía Ambiental (CIGA), Universidad Nacional Autónoma de México (UNAM), ${ }^{2}$ Institute of Environmental Science and Technology (ICTA), Autonomous University of Barcelona, Bellaterra, Spain 
various theoretical frameworks and network analysis to study the interrelations among land-use and management changes, cultural ecosystem services, and diverse causes, effects, and outcomes of environmental conflicts. Ingalls and Mansfield (2017) applied a coupled-systems and resilience approach using diverse causal mechanisms to explain social-ecological transformations in a region under armed conflict. However, these studies have either scarcely used spatial or quantitative information or they have analyzed it using statistical tools.

We use a regional case study to demonstrate an alternative approach that combines spatial and relational analyses to better grasp the relationships between different intensities of FCC and conflicts. By using semantically open accounting methods across a range of hierarchical levels, this approach allows us to coherently integrate and check the congruence of simultaneous, nonequivalent representations from spatial, quantitative, and qualitative information (Louie 2009, Rosen 2012, GonzálezLópez and Giampietro 2017). Relational analysis explores systems as sets of interdependent relations between functional elements, which express objectives necessary for the stability of the system, and structural elements, i.e., subparts of a functional element that share the same final objective and cooperate to express the emergent property, making possible their own reproduction (González-López and Giampietro et al. 2017). Relational analysis has recently been used to analyze deforestation using typologies of farming systems (Kovacic and Viteri Salazar 2017), but the incorporation of spatial analysis with this approach is still in its early stages (González-López and Giampietro 2017).

We first carry out spatial analysis to examine the spatial distribution of different FCC processes (deforestation, forest degradation, and forest conversion to avocado orchards) and conflicts of a range of expressions (from negotiation to fatal confrontations), and actors (individuals, communities, or the government) in the Meseta Purépecha region, in central Mexico. We then cluster communities according to such patterns and apply relational analysis to explore the composition and working of the different economic sectors and land-based activities of each subregion, combining quantitative information from secondary sources as well as local narratives from observant participation. Using this information, we explore the processes underlying the patterns of relations between FCC and conflicts observed in the three subregions. The Meseta Purépecha is an economically important forest region, with an internationally recognized experience of community forestry, and is the epicenter of international avocado production (Bofill Poch 2005, OrozcoRamírez et al. 2017). It also has a high percentage of indigenous populations and poverty rates (CDI 2010, CONEVAL 2014), acute deforestation and forest degradation processes (Mas et al. 2017), and recurrent episodes of conflict over illegal logging and landownership (Espín Díaz 1986, Vázquez León 2016).

Using relational analysis, we can combine quantitative assessments with the dynamics of social and ecological processes underlying FCC or environmental conflicts. That way we can focus on patterns and relationships rather than on absolute numbers and consider alternative explanations, dimensions, and representations of the study problem (Kovacic 2018). Moreover, the use of spatial analysis over a regional scale offers insights into patterns and heterogeneities across the territory beyond concrete cases. We suggest that this approach can be useful to deal with the uncertainties inherent in a wide range of complex environmental problems anywhere, especially when there is a lack of accurate and appropriate data.

\section{STUDY AREA}

The Meseta Purépecha is an elevated plateau ranging from 600 to $3818 \mathrm{~m}$ above sea level, with abundant volcanoes covered by oak, pine, and fir temperate forests. It is an important commercial forest region in Michoacán, a state that leads Mexico's resin production and ranks third in timber production (COFOM 2007). It is also the epicenter of international avocado production, which is rapidly expanding owing to high demand and prices in international markets. The region owes its name to the indigenous group inhabiting these lands before the Spanish conquest, the Purépecha, who are still widely present in the area. However, the demarcation made by the government of Michoacán covers 11 municipalities with heterogeneous land-tenure arrangements and ethnicity (Fig. 1).

Besides the territorial division of municipalities, $51 \%$ of the Mexican territory was distributed as common property because of the agrarian reform in force from 1917 until 1992 (TorresMazuera et al.2018). Over this period, groups of landless peasants could request collective land endowments through the concept of "ejidos," and indigenous communities could demand the restitution of the land that had been taken from them and could thereby become agrarian communities (Nuijten 1997). Agricultural land could be parceled and used individually but could not be sold or rented, whereas forests were to remain undivided (Klooster 2003). After a constitutional and agrarian reform in 1992, ejidos and agrarian communities could privatize and divide part or the totality of their collective land among assembly members, and sell or rent it to external agents (Randall 1996). The study area comprises 41 agrarian communities (161,231 ha), 51 ejidos (63,747 ha), 5 mixed communities, i.e., localities with both agrarian community and ejido (37,244 ha), and 131,567 ha of private property (Fig, 1). Unless otherwise stated, herein we will refer to both ejidos and agrarian communities as communities, for the sake of simplicity.

\section{MATERIALS AND METHODS}

\section{Spatial analysis}

We employed the land-cover/use maps developed by Mas et al. (2017) for the state of Michoacán to evaluate FCC processes. They applied a hybrid semiautomatic classification method that combined image segmentation, digital classification, and visual interpretation to SPOT satellite imagery from 2004 and 2014. These maps, with a global accuracy of $83.3 \%$ and a confidence interval of $3.1 \%$, are the most accurate land-cover/use data available for our study area (Mas et al. 2017). Nevertheless, the global accuracy of our maps is surely higher because our study area lacks land-cover/use areas subject to high spectral confusion, such as tropical dry forest and shrubland, and because we combined the 19 original classes into only 4, thus reducing omission and commission errors between spectrally similar classes. We considered primary forest, secondary forest, avocado orchards, and no forest. We used the perennial fruit trees class of our source land-cover/use map as proxy for avocado orchards because they represent $96 \%$ of the surface covered by perennial fruit trees in the study area (SIAP 2016). We computed the 
Fig. 1. Study area: (A) macro location, (B) land tenure arrangements, and (C) geographical map.
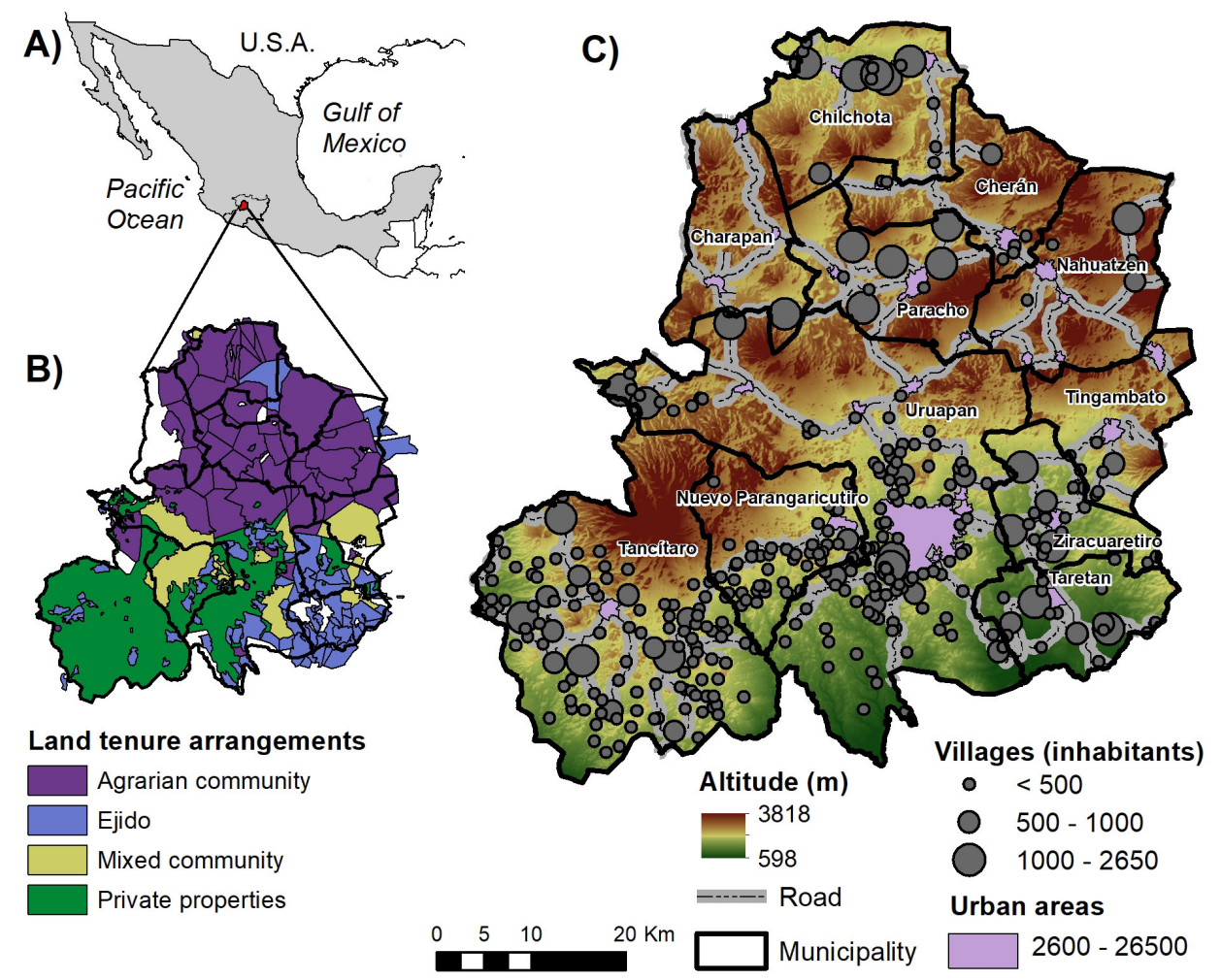

following: (1) forest degradation (change from primary to secondary forest), because this process is an indicator of selective logging in the area; (2) total deforestation (conversion of primary and secondary forest to nonforest); and (3) conversion of primary and secondary forest to avocado orchards, which is one of the main processes underlying forest loss in the study area (Barsimantov and Navia Antezana 2012).

We documented a total of 389 conflicts. We registered 161 forest conflicts between 2004 and 2014 from newspaper articles, academic literature, and interviews with key informants; 133 of them were caused by illegal logging and 28 related to ownership of the forest. We added to these 28, the 228 landownership conflicts reported by individuals from official censuses (lack of titles, land invasions, and agrarian conflicts; Appendix 1, Table A1.1). We characterized illegal logging and landownership conflicts according to the actors involved and their expression. To sort communities by FCC patterns, we performed a cluster analysis with the standardized values of the initial avocado extent, total forest loss, forest degradation, and spatial coordinates. We also mapped FCC (percentages of forest degradation, total deforestation, and forest conversion to avocado) and conflict intensity variables (number of conflicts weighted by the kind of actors involved and their expression, and per 1000 habitants) to explore their spatial patterns.

\section{Relational analysis}

Relational analysis explores expected patterns of relations between structural and functional elements. Structural elements describe the locations and compare the performances of different processes carried out for the same final aim, i.e., where and how the system does it (González-López and Giampietro 2018). We used data from official censuses to characterize the distribution of population (Appendix1, Table A1.2) and the annual benefits, i.e., income or equivalent monetary value of subsistence activities, (Appendix 1, Table A1.3) across the different economic sectors of each cluster. We considered the paid-work sector (which includes the primary, secondary, and tertiary sectors); the household sector (subsistence activities, care work, and dependents); and emigration (permanent and circular) and emigration flows. We then focused on the land-based activities (crop production, livestock breeding, and forestry) from the primary and subsistence sectors. Because part of the information used was aggregated at the municipal level, we excluded the municipality of Uruapan, which encompasses communities belonging to all the clusters identified as well as the city of Uruapan, the second largest city of the state, whose structure and function is quite different from that of a rural community.

Functional elements are associated with the definition of a goal, i.e., what the system does and why (González-López and Giampietro 2018). We characterized the functional elements of each subregion according to the local narratives to explore the processes underlying the various patterns of relations between FCC and conflicts. We gathered such information from 6 months of observant participation fieldwork and 59 semistructured interviews with government officials, foresters, researchers, authorities from various communities, and people involved in forest activities in the region. 


\section{RESULTS}

Spatial patterns of forest-cover change and conflicts

The cluster and visual analyses revealed three distinct spatial patterns of FCC and conflicts across the study area (Fig. 2). Initial total forest (primary plus secondary) amounted to $58.4 \%$ of the land cover in the north, $52.6 \%$ in the southeast, and $49.4 \%$ in the southwest (Table 1). Initial avocado orchards were mainly restricted to the south, where they represented around $38 \%$ of the land cover. The most important FCC was forest degradation (7.0\% in the north and 3.5\% in the southeast), conversion of secondary forest $(6.6 \%)$ and primary forest $(2.9 \%)$ to avocado orchards in the southeast, and secondary forest loss $(3.7 \%$ in the southeast and $2.4 \%$ in the north; Fig. 3, Table 1).

Fig. 2. Cluster analysis regarding forest-cover change (FCC) patterns per community.

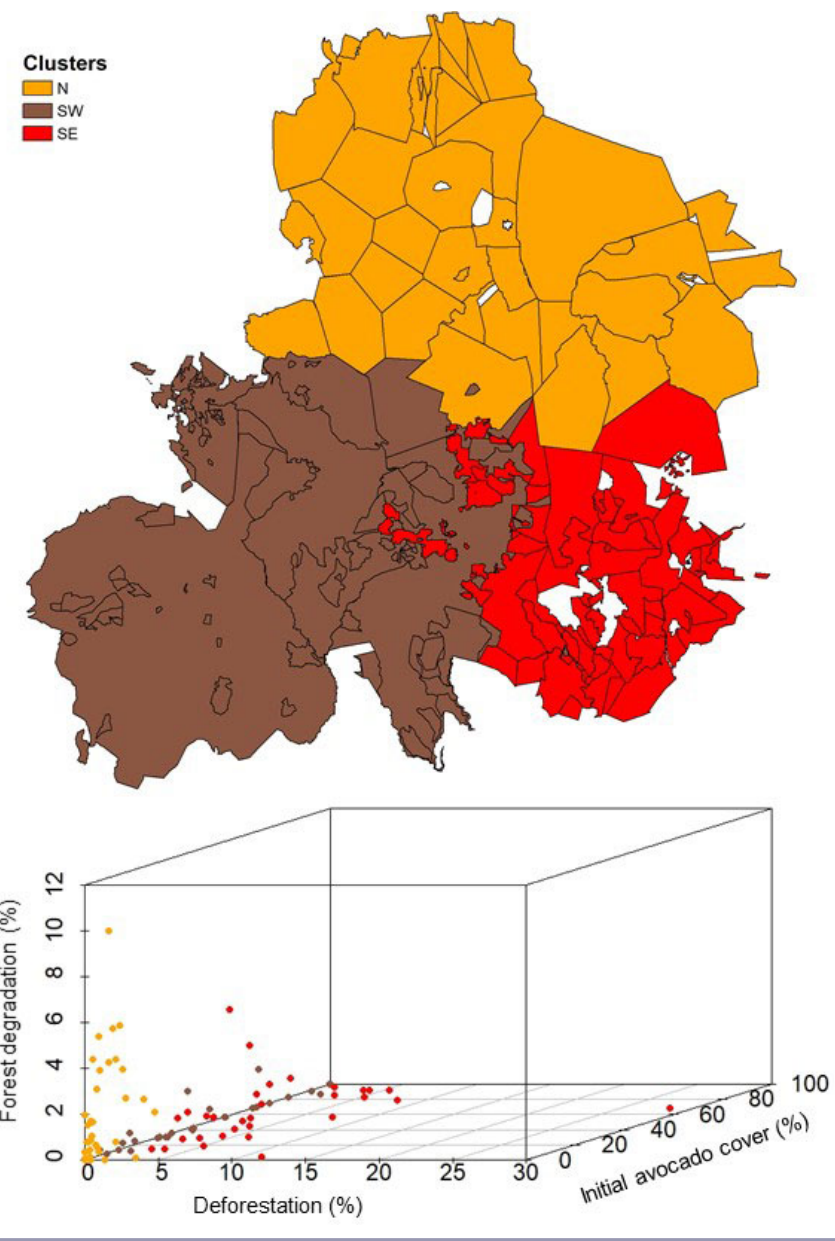

We registered 389 conflicts in total: 133 were caused by illegal logging and 256 were due to landownership issues (Fig. 4). With respect to the actors, 234 cases involved conflicts between individuals or groups, 85 were conflicts between communities, and 70 confronted communities with state actors. Regarding their expression, 140 involved direct actions, 91 confrontations, 84 tensions, 54 complaints, 11 fatal confrontations, and 9 negotiations.
Fig. 3. Maps representing: (A) the initial land-cover/use (2004), (B) forest-cover changes (2004-2014). Data obtained from the land-cover/use maps elaborated by Mas et. al (2017).

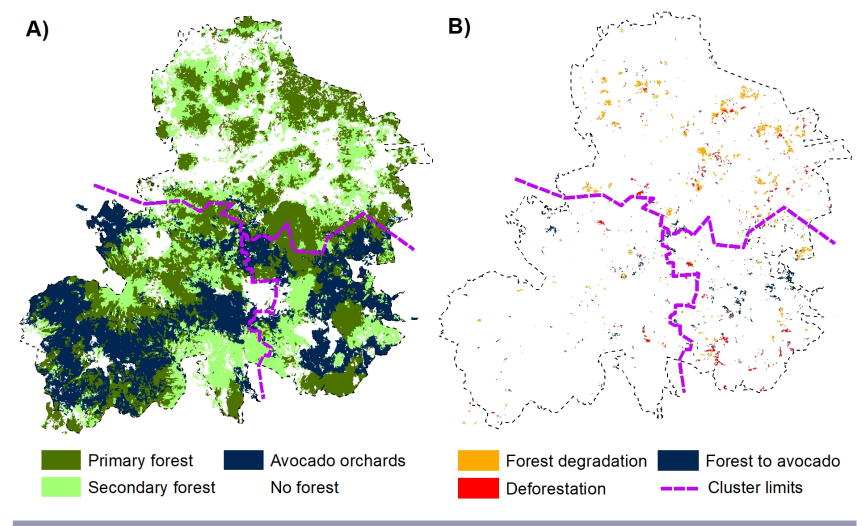

Fig. 4. Number of conflicts per subregion grouped by: (A) causes, (B) actors, and (C) expressions.
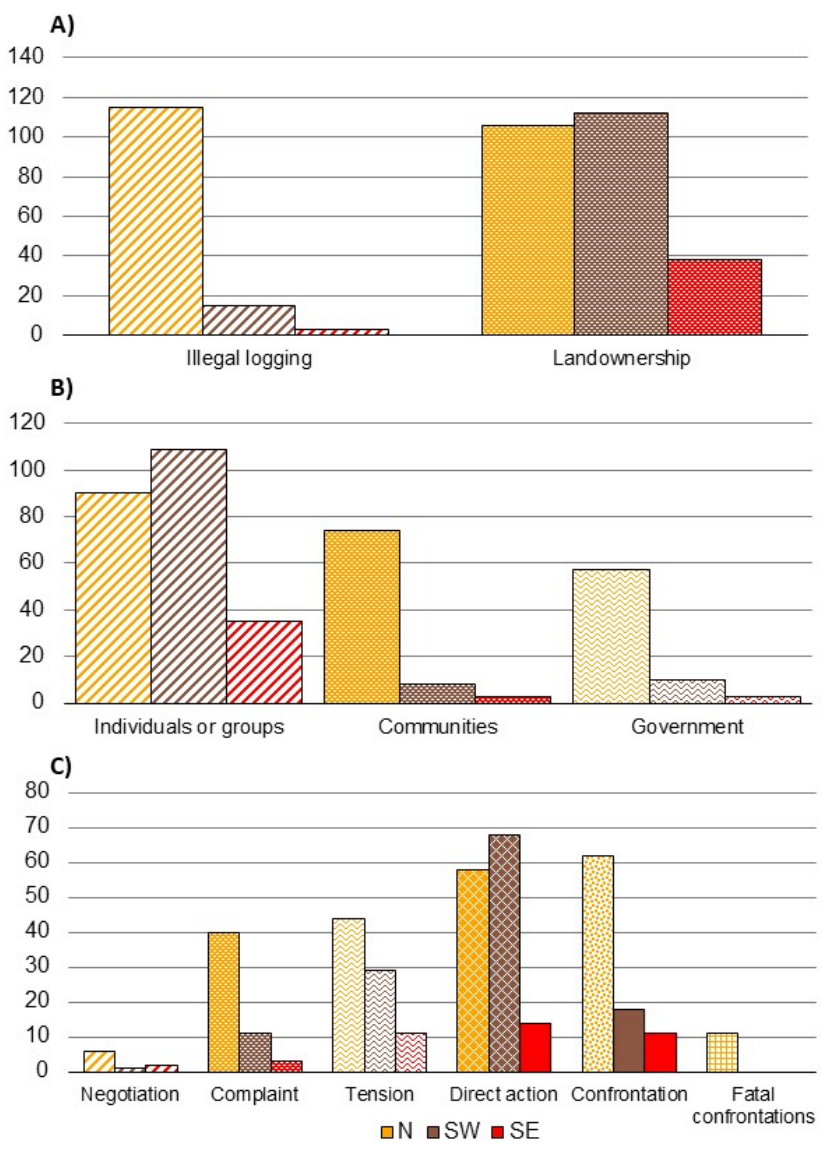

The north of the Meseta Purépecha held the highest absolute number and the highest proportion of communities with conflict because 27 of the 37 communities accounted for 221 of the conflicts. In the southwest, 11 of the 32 communities accounted 
Table 1. Matrix of percentages of forest-cover changes per subregion (2004-2014).

\begin{tabular}{|c|c|c|c|c|c|}
\hline \multirow[b]{2}{*}{2004} & \multicolumn{5}{|c|}{2014} \\
\hline & $\begin{array}{l}\text { Primary } \\
\text { forest }\end{array}$ & $\begin{array}{l}\text { Secondary } \\
\text { forest }\end{array}$ & Avocado & No forest & Total \\
\hline \multicolumn{6}{|l|}{ North } \\
\hline $\begin{array}{l}\text { Primary } \\
\text { forest }\end{array}$ & 91.71 & 7.02 & 0.40 & 0.88 & 32.55 \\
\hline $\begin{array}{l}\text { Secondary } \\
\text { forest }\end{array}$ & 1.24 & 96.05 & 0.34 & 2.37 & 25.86 \\
\hline Avocado & 0.30 & 0.41 & 98.66 & 0.63 & 1.38 \\
\hline No forest & 0.15 & 0.40 & 0.33 & 99.12 & 40.21 \\
\hline Total & 30.24 & 27.29 & 1.72 & 40.76 & 100.00 \\
\hline \multicolumn{6}{|l|}{ Southwest } \\
\hline $\begin{array}{l}\text { Primary } \\
\text { forest }\end{array}$ & 98.38 & 0.83 & 0.53 & 0.26 & 28.04 \\
\hline $\begin{array}{l}\text { Secondary } \\
\text { forest }\end{array}$ & 0.18 & 97.29 & 1.80 & 0.73 & 21.44 \\
\hline Avocado & 0.06 & 0.03 & 99.54 & 0.37 & 38.46 \\
\hline No forest & 0.07 & 0.16 & 0.62 & 99.15 & 12.05 \\
\hline Total & 27.66 & 21.13 & 38.90 & 12.32 & 100.00 \\
\hline \multicolumn{6}{|l|}{ Southeast } \\
\hline $\begin{array}{l}\text { Primary } \\
\text { forest }\end{array}$ & 92.01 & 3.48 & 2.95 & 1.56 & 29.38 \\
\hline $\begin{array}{l}\text { Secondary } \\
\text { forest }\end{array}$ & 0.73 & 88.97 & 6.59 & 3.71 & 23.26 \\
\hline Avocado & 0.03 & 0.21 & 98.91 & 0.85 & 39.35 \\
\hline No forest & 0.22 & 0.54 & 1.91 & 97.33 & 8.01 \\
\hline Total & 27.23 & 21.85 & 41.47 & 9.45 & 100.00 \\
\hline
\end{tabular}

for 127 conflicts; and in the southeast 8 of the 32 communities accounted for 41 conflicts. The intensity of conflicts regarding their actors and expression and their frequency per 1000 inhabitants showed similar patterns (Fig. 5). Conflicts over illegal logging were especially intense in the north, but their frequency was by comparison lower in many densely populated communities from this region and higher in a few small communities in the south. Landownership conflicts were, in general, less intense and more evenly distributed than conflicts over illegal logging, but their frequency was comparatively higher than their expression in some communities, especially in the southwest.

\section{Structural elements of communities}

Although in- and out-migration figures were similar in terms of relative population for all subregions, remittances were the primary source of benefits in the north amounting to $32 \%$ of the total versus $<3 \%$ in the south (Fig. 6). The proportions of population within the paid work and household sectors were similar across the whole Meseta Purépecha region (about 36\% and $63 \%$, respectively). Moreover, relative population was also very similar within the subsistence, care work, and dependents subsectors of the household sector. In all subregions, the primary sector held the highest proportion of employed population and relative benefits. However, the proportion of benefits from primary activities varied greatly between the southwest $(88 \%)$ and the north $(27 \%)$. All subregions had similar percentages of population within the secondary and tertiary sectors, although these were slightly lower in the southeast. The north held the highest relative benefits from secondary $(11 \%)$ and tertiary $(20 \%)$ activities.
Fig. 5. Intensity of conflicts per community regarding their kind of actors and expressions (A and B) and frequency per 1000 habitants (C and D).

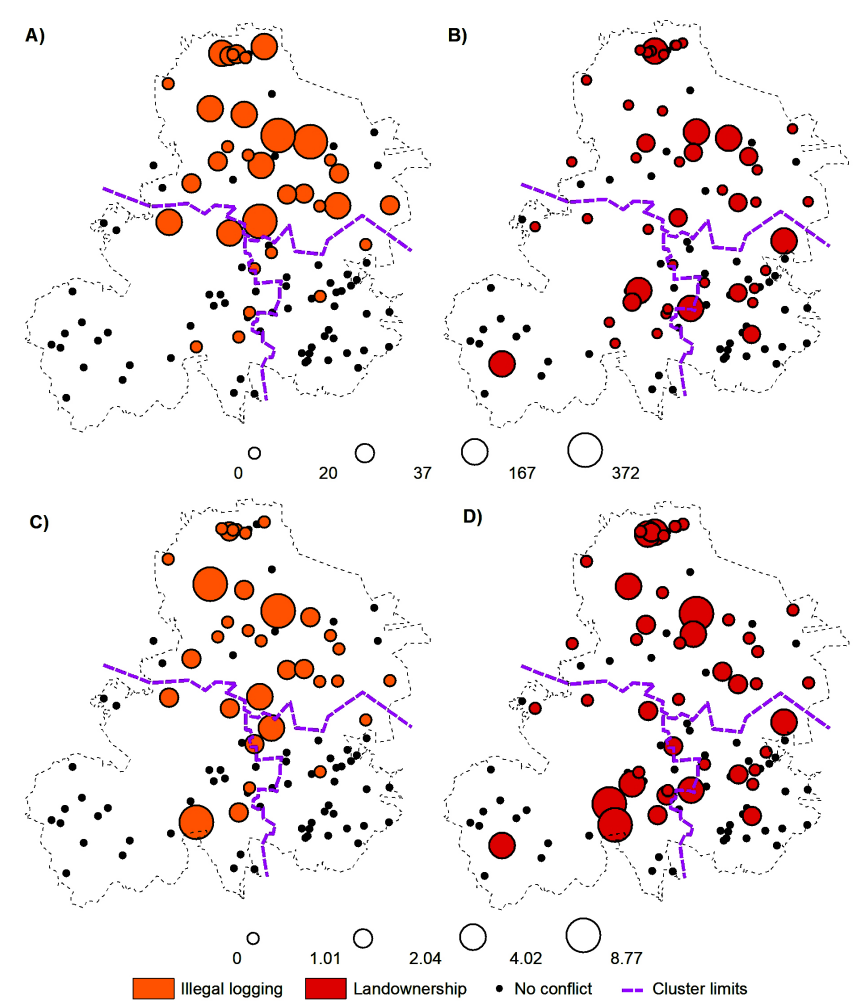

The total population involved in land-based activities was recorded as exceeding $100 \%$ because peasant households combined various activities (Fig. 7). Waged labor occupied the highest proportion of the population in all subregions. In terms of relative benefits, this activity ranked second in the north $(20 \%)$ but its contribution was moderate in the south $(<5 \%)$. Commercial crop production occupied $14.9 \%$ of the peasants in the north, and $23 \%$ in the southwest and southeast; it dominated the land-based economy in the southwest and provided most of the land-based benefits in the north. Commercial livestock breeding employed similar proportions of peasants across the three subregions (between $11 \%$ and $15 \%$ ). However, in the southeast it provided a higher share of the land-based benefits $(40 \%)$. Commercial forest activities involved fewer than $2 \%$ of peasants and generated less than $2 \%$ of benefits in all subregions.

The proportions of peasants practicing subsistence crop production and of benefits derived from it were substantial in the north $(26 \%$ and $15 \%$, respectively), but negligible in other subregions, especially in terms of benefits. Subsistence livestock breeding was the second source of land-based benefits in the southeast $(35 \%)$, and it was also important in the north $(10 \%)$. Subsistence forest activities were negligible in the three subregions, in terms of both peasants involved and benefits. 
Fig. 6. Relations between total benefits (TB) and total population (TP) for the various economic sectors within each subregion.

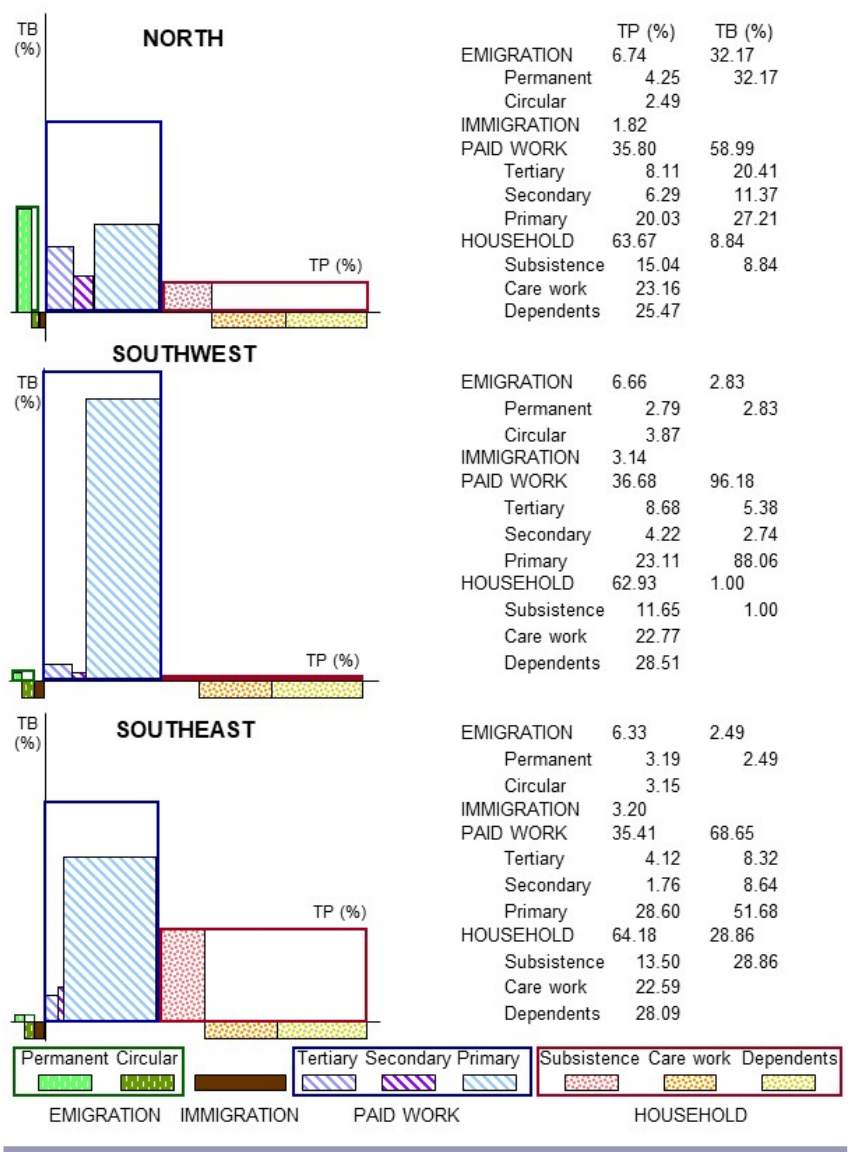

\section{Functional elements of communities}

\section{North subregion: illegal logging}

Land is scarce in the northern subregion, benefits derived from it reached a lower proportion of the population than in other subregions (Fig. 6), and the area per peasant was the lowest for all land-cover/use classes. Our fieldwork suggested that land is also unevenly distributed and many peasants, especially young household heads, lack rights to agricultural and forest plots. Moreover, land has limited productive capacity because of bioclimatic restrictions (frosts and cyclic water scarcity). Maize is the main crop in the north and it is mostly cultivated for subsistence purposes. Increasing competition due to the North America Free Trade Agreement, subsidies to producers in the USA, and the withdrawal of support to Mexican peasants have all rendered the sale of this crop profitless (Bello 2009, Thiébaut 2009). Other economic activities do not offer better alternatives; benefits per worker from the secondary and tertiary sectors were the lowest of all subregions. Remittances constitute the primary source of benefits; despite low official figures, about $40 \%$ of the population in some communities currently lives in the United States of America (Leco Tomás et al. 2009).
Fig. 7. Relations between total benefits (TB) and total population (TP) for the commercial and subsistence land-based activities of each subregion.

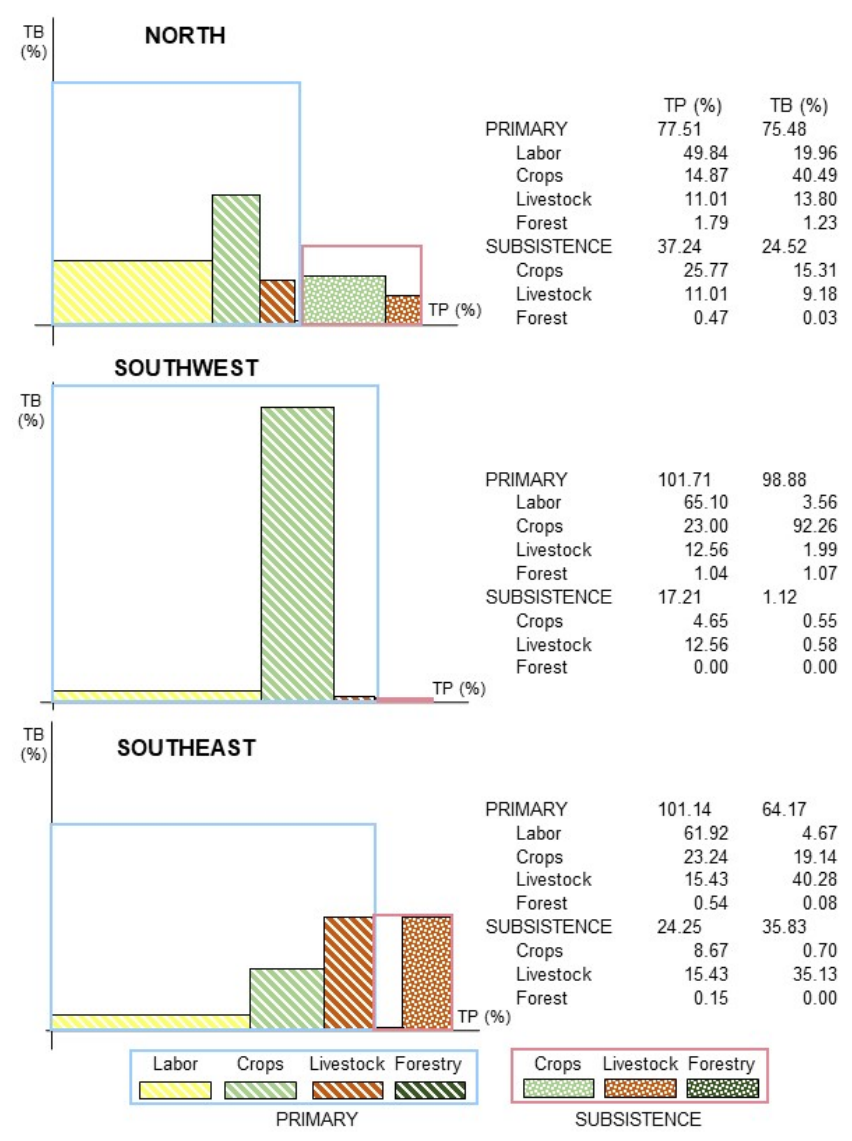

The high levels of forest degradation observed are probably caused by illegal logging, which is usually practiced on a small scale through the selection of the most commercially valuable trees and does not entail the complete removal of the forest cover. Although benefits and population involved in forestry are negligible compared to other productive and subsistence activities, its significance is certainly much higher than reported because about one-half of the timber industries and volume extracted in the Meseta Purépecha are illegal (COFOM 2007). Moreover, the traditional timber demand, associated with family carpentry and furniture workshops in this region, a nearby paper mill, and the national construction industry, has been augmented by the demand for wooden packing crates for the export of avocados (Espín Díaz 1986, Works and Hadley 2004, Thiébaut 2009).

Agrarian conflicts between communities are also common; official figures report about 50 conflicts of this kind in the north (Vázquez León 2016) and 250,000 ha in dispute (Jasso-Martínez 2010). They result from the historically ambiguous demarcation of boundaries between communities. However, timber extraction has intensified these landownership conflicts and created new tensions around the forest. Conflicts escalated because some communities who specialized in the production of boards, 
furniture, and packing crates, exhausted their supplies of commercial-grade timber. Timber businesses forged patronage relations with illegal loggers, who looted neighboring communities, became increasingly organized, armed themselves to confront forest holders, and received support from their extended families. Moreover, since 2007 the regional drugtrafficking cartel has been extorting illegal sawmills and loggers in exchange for protection. This situation reached a tipping point in 2011, when the indigenous community of Cherán rose up against illegal logging in its territory and successfully expelled the cartel (Fuentes Díaz and Paleta Pérez 2015).

\section{Southwest subregion: consolidation of avocado orchards}

The paid work sector of the southwest has the highest average benefits of all three subregions, but its economy is virtually dominated by avocado cultivation (Fig. 7). This activity considerably increases the amount of money flowing into communities; one hectare of avocado is worth approximately US $\$ 8000$ whereas one hectare of maize, the usual crop in the study area, is worth US\$800 (SIAP 2016). However, although waged labor employs most of the people involved in land-based activities, most of the benefits are captured by avocado producers, landowners, and middlemen. Benefits are thus very unequally distributed (Thiébaut 2009).

We observed little FCC in this subregion. However, most of the forest conversion to avocado orchards occurred before our remote sensing dataset. The first commercial avocado orchards were installed in the 1970s with the aid of appropriate infrastructure and optimal growing conditions, but since the US approved the importation of avocados in 1997, the orchards have exponentially expanded. The southwest still conserves a considerable amount of forest in which biophysical conditions are not optimal for avocado growth. Moreover, the successful community forestry company of San Juan Nuevo, in the municipality of Nuevo Parangaricutiro, and the presence of two resin plants nearby generate considerable profits, although for a small part of the population.

This subregion suffers a relatively high proportion of conflicts stemming from a lack of land titles and from land invasions. This dispossession was noted during our fieldwork; many small landowners had lost or sold their land to investors and big producers because of the high investment costs and lagged return on investments. Moreover, packing companies set up by the avocado elites or foreign capital have monopolized the commercialization of avocado and have fixed prices at their convenience (Ornelas 2018). Avocado production has also proceeded through coercion and violence (Maldonado Aranda 2014, Ornelas 2018). Since 2007, the regional drug-trafficking cartel has been purchasing or stealing orchards to launder money and has virtually controlled the market by extorting producers and packing companies through privileged access to official production data and a "silver or lead" policy, i.e., accept the bribe or risk being killed (Ornelas 2018). Some communities from the southwest indeed participated in the vigilante groups that took arms in 2013 to expel the organized crime from several municipalities of the state (Flannery 2017). In contrast, conflicts over deforestation are scarce.
Southeast subregion: expansion of avocado orchards

Benefits per employed inhabitant are quite high in the southeast; in the secondary and tertiary sectors they are at least twice as much as in the other subregions. This is in part due to the presence of a sugar mill and a poultry farm, which generate substantial direct and indirect employment. Benefits from the primary sector are also notably high, with livestock breeding being the primary land-based activity in terms of benefits provided; this consists mainly of poultry breeding, although revenues from cattle are also important. Commercial crop production has a long tradition in this area and ranges from sugarcane to fruit trees, fodder, and some vegetables, all cultivated alongside subsistence maize (SIAP 2016).

In this subregion, conversion of secondary forest to avocado orchards is rife. It is indeed one of the hotspots of avocado expansion in Michoacán (Mas et al. 2017), which is spreading mostly in both directions along an east-west axis following optimal bioclimatic conditions. Some commercial crops such as sugarcane and mangoes are being replaced by avocado orchards (SIAP 2016) because avocado renders considerably higher profits. However, avocado orchards are increasingly planted at the expense of primary forest. Forest owners are persuaded to sell their land, usually to middlemen who sometimes even burn or throw away the timber, plant avocados, and sell the orchards at a profit (Del Castillo 2008).

The southeast is composed mainly of ejidos and a small proportion of private property. Most landowners from ejidos secured titles to their individual plots, and land conflicts and invasions are less numerous and intense than in other subregions.

\section{DISCUSSION}

\section{Processes underlying forest-cover change and conflicts and interrelations between subregions}

Spatial and relational analyses revealed three distinct patterns of relations between FCC and conflict across the study area: (1) in the north, forest degradation was high and conflicts of varying intensity abundant and widespread, especially conflicts over illegal logging; (2) in the southwest, FCC levels were few but the initial avocado area was considerable, and conflicts were mostly over landownership; and (3) the southeast was undergoing intensive forest conversion to avocado crops and forest degradation but there were almost no conflicts.

We suggest that these diverging patterns correspond to different processes and temporalities. In the northern subregion, poverty and land scarcity might have pushed the population toward alternative sources of income. The importance of remittances points to constrained economic activities in this subregion. Moreover, the prevalence of subsistence activities suggests that land provides some households with strategic resources (food and fuel) that could not be acquired in the market owing to insufficient money. Migration and benefits from remittances have historically alleviated the population pressure and economic constraints. However, according to local informants, increasing timber demand has turned illegal logging into the best alternative for landless and unemployed young peasants because they do not have to leave their communities and a single tree can be sold for about US\$200, roughly the monthly salary of a laborer in nearby cash crops fields. The population has thus been able to survive at 
the expense of looted common forest resources, but this has exacerbated historical agrarian conflicts and provoked new ones over the appropriation of others' timber.

In the southwest subregion, large FCCs have occurred prior to the present study. Logging might indeed had facilitated this process, because avocados were usually planted over secondary forest owing to lower labor requirements (Barsimantov and Navia Antezana 2012). The consolidation of avocado orchards has seemingly provoked land grabbing and the concentration of the industry around big producers. These grievances are mostly confronted individually, probably because this subregion is composed mainly of private properties or ejido land, where many peasants secured individual titles to their parcels. In contrast, FCC might generate little opposition because profits are high and employment opportunities are generated by avocado growing, and because individual land titles make landowners fully responsible for their land-use decisions. However, violence from crime cartels might have deterred organized responses against forest clearance.

In the southeast, the high incidence of FCC might be related to the process of avocado expansion. Avocados are sometimes planted inside cleared forests to hide illegal land-use changes, and this could explain the observed forest degradation, although secondary forest loss probably corresponds to recently planted orchards because young avocado trees cannot be detected by our remote sensing dataset. Although there is massive conversion of secondary forests, avocado orchards are increasingly growing at the expense of primary forests because high returns compensate for the investment in forest clearing. Cattle might also have some effect on FCC because forage crops occupied the fourth largest area (SIAP 2016), and the proportion of pasture was higher than in the other subregions. Higher levels of benefits from other activities and initial benefits from the avocado growth have so far promoted social stability. However, coercion and violence from big avocado producers and drug cartels might increase landownership conflicts as in the southwest. The importance of the forest cover for water retention together with the intensive water requirements of avocado production could also create additional tensions in the whole region in the future (Friedmann and McNair 2008).

These FCCs and conflict patterns, although diverse, are nonetheless interrelated. The whole territory of the Meseta Purépecha has been reorganized by avocado production and its multiple secondary activities (Thiébaut 2009). These activities have differentially shaped the structure and function of each subregion and the interrelations between them. The avocado boom soon dominated the economy in the southwest. High profits from avocado have prompted conversion of forest and other commercial crops into avocado orchards in the southeast in response to optimal growing conditions; at the same time, a successful community forestry company has conserved a wide area of forest that is less suitable for avocado growing. Sawmills in the north provide below-cost packing crates from illegal timber, and subsistence activities help supply cheap labor for the nearby orchards. Thus, benefits along the commercialization chain are being extracted at the expense of human resources and the forests in the north (Reis 2019).

\section{Spatial and relational analyses to unravel complex relations in socio-natural systems}

By combining spatial and relational analyses, we were able to find contradictions and interpret diverse information to create a robust explanation of the processes underlying FCC and conflicts in the three subregions, as well as the complex relations among them. The methodological approach was useful in identifying patterns of relations more than exact quantities, and it also partially overcame the limitations regarding data availability and consequent uncertainty. In our case, these limitations were because of reliance on data from different sources, temporalities, sample sizes, and levels of aggregation, and to the absence of appropriate variables to explain some of the processes underlying both FCC and conflicts (especially migration and subsistence activities). Moreover, the comparison of data from different sources suggests considerable gaps in the information in the agriculture, livestock, and forestry census (our main source of information on land-based activities), especially for the north subregion. These gaps reflect the informal character of many land-tenure arrangements, timber extraction, and processing activities (COFOM 2007) and, within the rural population, the general mistrust of public officials (Mathews 2008).

Despite the limitations of our quantitative data, the use of complementary information from local narratives and a regional case study has illustrated the methodological approach we have developed, an approach that may help to unravel complex relations in socio-natural systems. Recent studies have analyzed the relation between land-use change and environmental conflicts by using complexity approaches (Hanaček and RodríguezLabajos 2018) or spatial analysis (Simmons 2004, Durán et al. 2011). However, the combination of the two approaches is still in its early stages (Ingalls and Mansfield 2017). By integrating spatial and relational analyses, we found diverse patterns of relations between FCC and conflicts in the Meseta Purépecha that were nonetheless interrelated and driven by the process of avocado production.

Using relational analysis, we decomposed the Meseta Purépecha region into three subregions that differed in their constituent components, analyzed their interactions and interdependent relations, and answered various questions to obtain a robust explanation of the FCC and conflicts observed in the three subregions. Whereas structural elements provide information about external constraints such as availability of natural resources, functional elements provide insights into the socioeconomic factors that impose internal constraints over natural systems (González-López and Giampietro 2017). Relational analysis thus allows critical examination of narratives that link FCC and conflicts by using different representations of the study problem. This approach deals with the complexity inherent in both processes, although this implies a lack of definitive answers about causality. Moreover, the integration of information from interviews shows patterns and relations between processes that quantitative data might hide. The use of spatial analysis greatly enhances this approach, especially regarding land-use processes because it accounts for the heterogeneities displayed by such processes across space. 


\section{CONCLUSION}

We have developed a methodological approach to unravel the underlying factors driving FCC and conflict, as well as the complex relations between the two processes. Our approach combines spatial and relational analyses to integrate and check the congruence of nonequivalent representations from quantitative sources and observant participation at various scales, and to explain the heterogeneity that processes display through space. We show that relations between FCC and conflict are not linear and depend on a combination of factors that hold interdependent, complex, and sometimes contradictory relations with the patterns observed. We suggest that this methodological approach can yield a more comprehensive and accurate representation of a wide range of complex environmental problems in any geographic or social context, or when the lack of accurate and appropriate data for capturing different dimensions of the study problem creates uncertainties.

Responses to this article can be read online at: http://www.ecologyandsociety.org/issues/responses. php/10992

\section{Acknowledgments:}

This work was funded through the project PAPIIT IN301215 from DGAPA-UNAM, the national scholarship program from CONACYT (number 558247/296508), and the scholarship CONACYT-SENER Sustentabilidad Energética (number 409781). Part of the data came from the Microdata Laboratory from INEGI and we acknowledge the kindness of its staff. We are indebted to all the interviewees and community members for their time, knowledge, and hospitality during fieldwork. We are also grateful to Ann Grant for her revision and language edition of the manuscript.

\section{LITERATURE CITED}

Affolderbach, J. 2011. Environmental bargains: power struggles and decision making over British Columbia's and Tasmania's oldgrowth forests. Economic Geography 87(2):181-206. http://dx.doi. org/10.1111/j.1944-8287.2011.01107.x

Aldrich, S., R. Walker, C. Simmons, M. Caldas, and S. Perz. 2012. Contentious land change in the Amazon's arc of deforestation. Annals of the Association of American Geographers 102 (1):103-128. http://dx.doi.org/10.1080/00045608.2011.620501

Araujo, C., C. A. Bonjean, J.-L. Combes, P. Combes Motel, and E. J. Reis. 2009. Property rights and deforestation in the Brazilian Amazon. Ecological Economics 68(8-9):2461-2468. http://dx.doi. org/10.1016/j.ecolecon.2008.12.015

Barsimantov, J., and J. Navia Antezana. 2012. Forest cover change and land tenure change in Mexico's avocado region: is community forestry related to reduced deforestation for high value crops? Applied Geography 32(2):844-853. http://dx.doi.org/10.1016/j. apgeog.2011.09.001

Bello, W. F. 2009. Eroding the Mexican countryside. Pages 39-53 in W. F. Bello, editor. The food wars. Verso, London, UK.
Bofill Poch, S. 2005. El bosque político: los avatares de la construcción de una comunidad modelo, San Juan Nuevo, Michoacán, 1981-2001. El Colegio de Michoacán, Universidad de Barcelona, Zamora, Mexico.

Comisión Forestal del Estado de Michoacán (COFOM). 2007. Programa de desarrollo forestal sustentable del Estado de Michoacán 2030. Tomo I. Comisión Forestal del Estado de Michoacán, Morelia, Mexico. [online] URL: http://www.conafor. gob.mx:8080/documentos/docs/43/6046La $\% 20$ producci $\% \mathrm{C} 3 \% \mathrm{~B} 3 \mathrm{n} \%$ 20de $\% 20$ resina $\% 20$ de $\% 20$ pino $\% 20$ en $\% 20 \mathrm{M} \%$ C3 $\%$ A 9 xico.pdf

Comisión Forestal del Estado de Michoacán (COFOM). 2007. Programa de desarrollo forestal sustentable del Estado de Michoacán 2030. Tomo I. Comisión Forestal del Estado de Michoacán, Morelia, Mexico. [online] URL: http://www.conafor. gob.mx:8080/documentos/docs/43/6046La $\% 20$ producci $\% \mathrm{C} 3 \% \mathrm{~B} 3 \mathrm{n} \%$ 20de $\% 20$ resina $\% 20$ de $\% 20$ pino $\% 20$ en $\% 20 \mathrm{M} \%$ C $3 \%$ A 9 xico.pdf

Comisión Nacional Forestal (CONAFOR). 2013. La producción de resina de pino en México. Comisión Nacional Forestal, Mexico City, Mexico. [online] URL: https://www.gob.mx/cms/uploads/ attachment/file/80999/Estudio__ La_produccion_de resina_de pino en Mexico.pdf

Comisión Nacional Para el Desarrollo de los Pueblos Indígenas (CDI). 2010. Catálogo de localidades indígenas 2010. Comisión Nacional Para el Desarrollo de los Pueblos Indígenas, Mexico City, Mexico. [online] URL: http://www.cdi.gob.mx/localidades2010gobmx/

Consejo Nacional de Evaluación de la Política de Desarrollo Social (CONEVAL). 2014. Medición de la pobreza en México 2010, a escala municipal. Consejo Nacional de Evaluación de la Política de Desarrollo Social, Mexico City, Mexico. [online] URL: https://www.coneval.org.mx/Medicion/Paginas/consulta_pobreza municipal.aspx

Corson, C. 2011. Territorialization, enclosure and neoliberalism: non-state influence in struggles over Madagascar's forests. Journal of Peasant Studies 38(4):703-726. http://doi.org/10.1080/030661$\underline{50.2011 .607696}$

Del Castillo, A. 2008. Michoacán: la fiebre del "oro verde." Público-Milenio, 14 December. [online] URL: http://verdebandera. $\underline{\mathrm{mx} / \mathrm{mich} \text { oacan-la-fiebre-del-oro-verde/ }}$

Durán, E., D. B. Bray, A. Velázquez, and A. Larrazábal. 2011. Multi-scale forest governance, deforestation, and violence in two regions of Guerrero, Mexico. World Development 39(4):611-619. http://doi.org/10.1016/j.worlddev.2010.08.018

Espín Díaz, J. L. 1986. Tierra fría, tierra de conflictos en Michoacán. El Colegio de Michoacán, Zamora, México.

Flannery, N. P. 2017. Mexico's avocado army: how one city stood up to the drug cartels. Guardian 18 May. [online] URL: https:// www.theguardian.com/cities/2017/may/18/avocado-police-tancitaromexico-law-drug-cartels

Friedmann, H., and A. McNair. 2008. Whose rules rule? Contested projects to certify 'local production for distant consumers.' Journal of Agrarian Change 8(2-3):408-434. https:// doi.org/10.1111/j.1471-0366.2008.00175.x 
Fuentes Díaz, A., and G. Paleta Pérez. 2015. Violencia y autodefensas comunitarias en Michoacán, México. Iconos. Revista de Ciencias Sociales (53):171-186.

Funtowicz, S., and J. R. Ravetz. 1994. Emergent complex systems. Special Issue Complexity: Fad or Future? 26(6):568-582. https:// doi.org/10.1016/0016-3287(94)90029-9

Gerber, J.-F., and S. Veuthey. 2011. Possession versus property in a tree plantation socioenvironmental conflict in Southern Cameroon. Society and Natural Resources 24(8):831-848. http:// doi.org/10.1080/08941920.2010.521887

Giampietro, M., R. J. Aspinall, J. Ramos-Martin, and S. G. F. Bukkens. 2014. Resource accounting for sustainability assessment: the nexus between energy, food, water and land use. Routledge, London, UK. https://doi.org/10.4324/9781315866895

Glew, L., and M. D. Hudson. 2007. Gorillas in the midst: the impact of armed conflict on the conservation of protected areas in sub-Saharan Africa. Oryx 41(2):140-150. https://doi. org/10.1017/S0030605307001755

González-López, R., and M. Giampietro. 2017. Multi-scale integrated analysis of charcoal production in complex socialecological systems. Frontiers in Environmental Science 5:54. http:// doi.org/10.3389/fenvs.2017.00054

González-López, R., and M. Giampietro. 2018. Relational analysis of the oil and gas sector of Mexico: implications for Mexico's energy reform. Energy 154:403-414. http://doi. org/10.1016/j.energy.2018.04.134

Hanaček, K., and B. Rodríguez-Labajos. 2018. Impacts of landuse and management changes on cultural agroecosystem services and environmental conflicts - a global review. Global Environmental Change 50:41-59. http://doi.org/10.1016/j. gloenvcha.2018.02.016

Hecht, S. B., and A. Cockburn. 2010. The fate of the forest: developers, destroyers, and defenders of the Amazon. Updated edition. University of Chicago Press, Chicago, Illinois, USA.

Ingalls, M. L., and D. Mansfield. 2017. Resilience at the periphery: insurgency, agency and social-ecological change under armed conflict. Geoforum 84:126-137. http://doi.org/10.1016/j. geoforum.2017.06.012

Jasso-Martínez, I. J. 2010. Las demandas agrarias en el discurso de las organizaciones purépechas de Michoacán: problemas sin resolver. Ra Ximhai 6(2):229-241. https://doi.org/10.35197/ rx.06.02.2010.06.ij

Klooster, D. 2003. Campesinos and Mexican forest policy during the twentieth century. Latin American Research Review 38 (2):94-126. https://doi.org/10.1353/lar.2003.0018

Koning, R., D. Capistrano, Y. Yasmi, and P. Cerutti. 2008. Forestrelated conflict. Impacts, links, and measures to mitigate. Rights and Resources Initiative, Washington, D.C., USA. http://www. apafri.org/activities/Bhutan2013/publication $/ \mathrm{m} 8 \%$ 20forest $\% 20$ related $\%$ 20conflict.pdf

Kovacic, Z. 2018. Conceptualizing numbers at the science-policy interface. Science, Technology, and Human Values 43 (6):1039-1065. https://doi.org/10.1177/0162243918770734
Kovacic, Z., and O. Viteri Salazar. 2017. The lose-lose predicament of deforestation through subsistence farming: unpacking agricultural expansion in the Ecuadorian Amazon. Journal of Rural Studies 51:105-114. http://doi.org/10.1016/j. jrurstud.2017.02.002

Leco Tomás, C., A. Kido-Cruz, and R. Molina Martínez. 2009. Migración indígena a Estados Unidos. Purhépechas en Burnsville Norte Carolina. UMSNH, ININEE, CIMEXUS CIC, FH, Secretaría del Migrante, Morelia, México.

Louie, A. H. 2009. More than life itself: a synthetic continuation in relational biology. Ontos Verlag, Frankfurt, Germany. https:// doi.org/10.1515/9783110321944

Maldonado Aranda, S. 2014. "You don't see any violence here but it leads to very ugly things": forced solidarity and silent violence in Michoacán, Mexico. Dialectical Anthropology 38 (2):153-171. http://doi.org/10.1007/s10624-014-9335-4

Mas, J.-F., R. Lemoine-Rodríguez, R. González-López, J. LópezSánchez, A. Piña-Garduño, and E. Herrera-Flores. 2017. Land use/land cover change detection combining automatic processing and visual interpretation. European Journal of Remote Sensing 50 (1):626-635. http://doi.org/10.1080/22797254.2017.1387505

Mathews, A. S. 2008. State making, knowledge, and ignorance: translation and concealment in Mexican forestry institutions. American Anthropologist 110(4):484-494. https://doi.org/10.1111/ j.1548-1433.2008.00080.x

McNeely, J. A. 2003. Biodiversity, war, and tropical forests. Journal of Sustainable Forestry 16(3-4):1-20. http://doi. org/10.1300/J091v16n03 01

McSweeney, K., E. A. Nielsen, M. J. Taylor, D. J. Wrathall, Z. Pearson, O. Wang, and S. T. Plumb. 2014. Drug policy as conservation policy: narco-deforestation. Science 343(6170):489-490. https://doi.org/10.1126/science.1244082

Nuijten, M. 1997. Agrarian reform and the ejido in Mexico; illegality within the framework of the law. Pages 72-104 in R. Kuppe and R. Potz, editors. Natural resources, environment, and legal pluralism. Martinus Nijhoff, The Hague, The Netherlands.

O'Brien, K. 1998. Sacrificing the forest: environmental and social struggles in Chiapas. Westview, Boulder, Colorado, USA. https:// doi.org/10.4324/9780429497476

Ornelas, R. G. 2018. Organized crime in Michoacán: rent-seeking activities in the avocado export market. Politics and Policy 46 (5):759-789. http://doi.org/10.1111/polp.12270

Orozco-Ramírez, Q., M. Astier, and S. Barrasa. 2017. Agricultural land use change after NAFTA in Central West Mexico. Land 6(4):66. http://doi.org/10.3390/land6040066

Peluso, N. L., and C. Lund. 2011. New frontiers of land control: introduction. Journal of Peasant Studies 38(4):667-681. http://doi. org/10.1080/03066150.2011.607692

Randall, L. 1996. Reforming Mexico's agrarian reform. M.E. Sharpe, Armonk, New York, USA.

Reis, N. 2019. A farewell to urban/rural bias: peripheral finance capitalism in Mexico. Journal of Peasant Studies 46:702-728. http://doi.org/10.1080/03066150.2017.1395856 
Rincón-Ruiz, A., and G. Kallis. 2013. Caught in the middle, Colombia's war on drugs and its effects on forest and people. Geoforum 46:60-78. https://doi.org/10.1016/j.geoforum.2012.12.009

Rocheleau, D. E. 2015. Networked, rooted and territorial: green grabbing and resistance in Chiapas. Journal of Peasant Studies 42 (3-4):695-723. http://doi.org/10.1080/03066150.2014.993622

Rodrigues, A. S. L., R. M. Ewers, L. Parry, C. Souza, Jr., A. Veríssimo, and A. Balmford. 2009. Boom-and-bust development patterns across the Amazon deforestation frontier. Science 324 (5933):1435-1437. http://doi.org/10.1126/science.1174002

Rosen, R. 1999. Essays on life itself. Columbia University Press, New York, New York, USA.

Rosen, R. 2012. Anticipatory systems. Philosophical, mathematical, and methodological foundations. Vol. 1. Springer, New York, New York, USA.

Rustad, S. C. A., J. K. Rød, W. Larsen, and N. P. Gleditsch. 2008. Foliage and fighting: forest resources and the onset, duration, and location of civil war. Political Geography 27(7):761-782. http:// doi.org/10.1016/j.polgeo.2008.09.004

Saltelli, A., and M. Giampietro. 2017. What is wrong with evidence based policy, and how can it be improved? Futures 91:62-71. https://doi.org/10.1016/j.futures.2016.11.012

Sánchez-Cuervo, A. M., and T. M. Aide. 2013. Consequences of the armed conflict, forced human displacement, and land abandonment on forest cover change in Colombia: a multi-scaled analysis. Ecosystems 16(6):1052-1070. http://doi.org/10.1007/ $\underline{\mathrm{s} 10021-013-9667-\mathrm{y}}$

Seghezzo, L., J. N. Volante, J. M. Paruelo, D. J. Somma, E. C. Buliubasich, H. E. Rodríguez, S. Gagnon, and M. Hufty. 2011. Native forests and agriculture in Salta (Argentina): conflicting visions of development. Journal of Environment and Development 20(3):251-277. http://doi.org/10.1177/1070496511416915

Servicio de Información Agroalimentaria y Pesquera (SIAP). 2016. Estadística de producción agrícola. Servicio de Información Agroalimentaria y Pesquera, Mexico City, Mexico. [online] URL: http://infosiap.siap.gob.mx/gobmx/datosAbiertos.php

Simmons, C. S. 2004. The political economy of land conflict in the eastern Brazilian Amazon. Annals of the Association of American Geographers 94(1):183-206. http://doi.org/10.1111/ j.1467-8306.2004.09401010.x

Suthakar, K., and E. N. Bui. 2008. Land use/cover changes in the war-ravaged Jaffna Peninsula, Sri Lanka, 1984-early 2004. Singapore Journal of Tropical Geography 29(2):205-220. https:// doi.org/10.1111/j.1467-9493.2008.00329.x

Thiébaut, V. 2009. La libéralisation économique et la restructuration des territoires ruraux au Mexique: L'exemple de la culture de l'avocat dans l'État de Michoacán. Cahiers de géographie du Québec 53(148):63-81. https://doi.org/10.7202/038142ar

Torres-Mazuera, G., J. Fernández Mendiburu, and C. Gómez Godoy. 2018. Informe sobre la jurisdicción agraria y los derechos de los pueblos indígenas y campesinos en México. Fundación para el Debido Proceso, Washington, D.C., USA. [online] URL: http:// www.dplf.org/sites/default/files/informe_jurisdiccion_agraria_ve$\underline{\text { rsion final.pdf }}$
Vázquez León, L. 2016. Multiculturalism as a juridical weapon: the use and abuse of the concept of 'Pueblo Originario' in agrarian conflicts in Michoacán, Mexico. Pages 35-73 in D. Lehmann, editor. The crisis of multiculturalism in Latin America. Palgrave Macmillan, New York, New York, USA.

Veldkamp, A., and E. F. Lambin. 2001. Predicting land-use change. Agriculture, Ecosystems and Environment 85(1):1-6. https://doi.org/10.1016/S0167-8809(01)00199-2

Works, M. A., and K. S. Hadley. 2004. The cultural context of forest degradation in adjacent Purépechan communities, Michoacán, Mexico. Geographical Journal 170(1):22-38. https:// doi.org/10.1111/j.0016-7398.2004.05024.x 
Appendix 1. Variables used in spatial and relational analyses

Table A1.1. Variables used for characterizing forest conflicts

Variable name Description

Actors in conflict Categories: individuals or groups; communities; government

Causes of conflict Categories: illegal logging; landownership

Intensities of conflict Categories and examples: negotiation (conciliation); complaint (legal complaints); tension (threats, protracted and latent conflicts, lack of land titles); direct action (protests, roadblocks, kidnappings, land invasions); confrontation (violent clashes, sometimes with injured people, land disputes); killing (violent clashes that result in deaths)

Weighted conflicts Sum of the forest conflicts multiplied by their intensity (1=negotiation, $2=$ complaints, $3=$ tension, $4=$ direct actions, $5=$ confrontations, $6=$ deadly confrontations) and actors ( $2=$ individuals or groups, $4=$ communities, $6=$ government) for each community

$\dagger$ Conflicts were documented from secondary sources (newspaper articles, academic literature, and interviews with key informants) and from the 2007 Agricultural, livestock and forestry census. 
Table A1.2. Variables used for characterizing population in relational analyses

\begin{tabular}{|c|c|c|}
\hline Category & Source & Description \\
\hline Migration & $\mathrm{PC}$ & $\begin{array}{l}\text { Population involved in permanent or circular migration (sum of migration } \\
\text { subcategories) }\end{array}$ \\
\hline Permanent & $\mathrm{PC}$ & $\begin{array}{l}\text { Population that emigrated to the United States of America between } 2005 \text { and } \\
2010 \text { and remained there during the census survey }\end{array}$ \\
\hline Circular & $\mathrm{PC}$ & $\begin{array}{l}\text { Population that resided in United States of America or in another Mexican state } \\
\text { in June } 2005 \text { but were back during the census survey }\end{array}$ \\
\hline Immigration & $\mathrm{PC}$ & Population born in another state \\
\hline Total & $\mathrm{PC}$ & Population residing habitually in the locality \\
\hline Paid work & $\mathrm{PC}$ & $\begin{array}{l}\text { Economically active population (population over } 12 \text { years old employed or that } \\
\text { looked for a job in the week before the survey) }\end{array}$ \\
\hline Tertiary & $\mathrm{EC}$ & Population employed in the tertiary sector \\
\hline Secondary & $\mathrm{EC}$ & Population employed in the secondary sector \\
\hline Primary & ALF & $\begin{array}{l}\text { Population employed in the primary sector (sum of primary sector } \\
\text { subcategories) }\end{array}$ \\
\hline Agriculture & ALF & $\begin{array}{l}\text { Population involved in commercial agriculture (sum of agricultural households } \\
\text { that sell all their crops plus half of the ones that sell part of their crops) }\end{array}$ \\
\hline Livestock & ALF & $\begin{array}{l}\text { Population involved in commercial livestock breeding (half of the peasant } \\
\text { households that own livestock) }\end{array}$ \\
\hline Forest & ALF & $\begin{array}{l}\text { Population engaged in commercial forest activities (sum of the peasant } \\
\text { households involved in timber processing, logging or resin tapping) }\end{array}$ \\
\hline Labor & ALF & Population hired in the primary sector \\
\hline Household & $\mathrm{PC}$ & $\begin{array}{l}\text { Population that belongs to the household sector (sum of economically inactive } \\
\text { population plus population between } 0 \text { and } 12 \text { years old) }\end{array}$ \\
\hline Subsistence & ALF & $\begin{array}{l}\text { Population involved in subsistence activities (population retired and involved } \\
\text { in housework minus the total economically inactive population) }\end{array}$ \\
\hline Agriculture & ALF & $\begin{array}{l}\text { Population that grow crops for self-consumption (sum of agricultural } \\
\text { households that consume all their crops plus half of the ones that consume part } \\
\text { of them) }\end{array}$ \\
\hline Livestock & ALF & $\begin{array}{l}\text { Population that breed animals for self-consumption (half of the peasant } \\
\text { households that own livestock) }\end{array}$ \\
\hline Forest & ALF & $\begin{array}{l}\text { Population that extract forest products for domestic purposes (number of } \\
\text { peasant households that collect firewood) }\end{array}$ \\
\hline Care work & $\mathrm{PC}$ & Population over 12 years engaged in housework \\
\hline Dependents & $\mathrm{PC}$ & $\begin{array}{l}\text { Dependent population (population retired plus the population between } 0 \text { and } 12 \\
\text { years old) }\end{array}$ \\
\hline \multicolumn{3}{|c|}{$\begin{array}{l}\dagger \text { PC stands for } 2010 \text { Population census, gathered from published data at locality level; EC for } 2009 \\
\text { Economic census, gathered from published data at municipal level; and ALF for } 2007 \text { Agricultural, } \\
\text { livestock and forestry census, gathered from microdata at locality level. All censuses come from the } \\
\text { National Institute of Statistics and Geography (INEGI) }\end{array}$} \\
\hline
\end{tabular}


Table A1.3. Variables used for characterizing benefits in relational analysis

\begin{tabular}{|c|c|c|}
\hline Category & Source & Description \\
\hline Migration & CONAPO & Benefits received as remittances in 2004 \\
\hline Total & EC, SIAP, ALF & $\begin{array}{l}\text { Annual benefits (sum of remittances plus benefits from the paid } \\
\text { work and subsistence sectors) }\end{array}$ \\
\hline Paid work & EC, SIAP, ALF & $\begin{array}{l}\text { Annual benefits plus salaries from the paid work sector (sum of } \\
\text { benefits from all the economic sectors) }\end{array}$ \\
\hline Tertiary & $\mathrm{EC}$ & Annual net benefits plus salaries from the tertiary sector \\
\hline Secondary & EC & Annual net benefits plus salaries from the secondary sector \\
\hline Primary & SIAP, ALF & Annual net benefits plus salaries from the primary sector \\
\hline Agriculture & SIAP & $\begin{array}{l}\text { Annual gross benefits from commercial agriculture (sum of the } \\
\text { value of all produce except corn) }\end{array}$ \\
\hline Livestock & SIAP & $\begin{array}{l}\text { Annual gross benefits from commercial livestock breeding } \\
\text { (value of all livestock products except standing livestock) }\end{array}$ \\
\hline Forest & ALF & $\begin{array}{l}\text { Annual gross benefits from timber and resin extraction. } \\
\text { Computed using } 7400 \mathrm{MXN} \text { as the price per tone of } \operatorname{resin}^{1} \text {, and } \\
1227 \mathrm{MXN} \text { as the price of timber per cubic meter }\end{array}$ \\
\hline Labor & ALF & $\begin{array}{l}\text { Annual benefits obtained as salaries in the primary sector. } \\
\text { Computed using } 4000 \mathrm{MXN} \text { as the monthly salary of a laborer }\end{array}$ \\
\hline Subsistence & SIAP, ALF & $\begin{array}{l}\text { Annual monetary value from subsistence activities (sum of the } \\
\text { subsistence categories) }\end{array}$ \\
\hline Agriculture & SIAP & $\begin{array}{l}\text { Annual monetary value from subsistence agriculture. We } \\
\text { assumed that all the corn cultivated was for self-consumption }\end{array}$ \\
\hline Livestock & SIAP & $\begin{array}{l}\text { Annual monetary value from subsistence livestock breeding. We } \\
\text { equated subsistence livestock breeding to the standing livestock. } \\
\text { We only used bovine cattle in Figure } 7\end{array}$ \\
\hline Forest & ALF & $\begin{array}{l}\text { Annual monetary value from firewood collection. We used } 100 \\
\text { MXN as the price per cubic meter of firewood }{ }^{3}\end{array}$ \\
\hline \multicolumn{3}{|c|}{$\begin{array}{l}\dagger \text { CONAPO stands for National Population Council, from the Bank of Mexico, gathered from } \\
\text { published data from } 2014 \text { at municipal level; EC for } 2009 \text { Economic census, from INEGI, gathered } \\
\text { from published data at municipal level; SIAP for Agri-food and Fisheries Information Service from } \\
\text { SAGARPA, gathered from published data from } 2007 \text { at municipal level; and ALF for } 2007 \\
\text { Agricultural, livestock and forestry census, from INEGI, gathered from microdata at locality level. } \\
{ }^{1} \text { CONAFOR (2013), }{ }^{2} \text { CONAFOR (2010), }{ }^{3} \text { COFOM }(2007)\end{array}$} \\
\hline
\end{tabular}

